\begin{tabular}{|l|l|l|l|l|l|}
\hline J. Tek. Ling & Vol. 13 & No. 2 & Hal. 221 - 230 & Jakarta, Mei 2012 & ISSN 1441-318X \\
\hline
\end{tabular}

\title{
SELEKSI JAMUR TANAH PENDEGRADASI SELULOSA DAN PESTISIDA DELTAMETHRIN DARI BEBERAPA LINGKUNGAN DI KALIMANTAN BARAT
}

\author{
Yohanes Bernard Subowo \\ Peneliti di Bidang Mikrobiologi, Puslit Biologi-LIPI \\ E-mail: yosubowo@yahoo.com
}

\begin{abstract}
Abstrak
Telah dilakukan penelitian mengenai seleksi jamur tanah pengurai selulosa dan deltamethrin dari beberapa lingkungan di Kalimantan Barat. Tujuan penelitian untuk memperoleh isolat jamur yang mampu menguraikan selulosa dan pestisida deltamethrin. Sampel tanah diambil dari beberapa lingkungan ekstrim di Kalimantan Barat meliputi: tanah gambut, tanah kering, tanah pantai, tanah pertanian dan tanah mangrove. Setelah dilakukan isolasi diperoleh 79 nomor isolat. Sebanyak 72 isolat dapat membentuk clear zone pada media mengandung CMC $1 \%$. Sejumlah 10 isolat membentuk clear zone berukuran besar. Jamur Aspergillus niger PS 1.4 dapat tumbuh paling baik pada media mengandung $\mathrm{CMC} 1 \%$ dengan menghasilkan bobot biomassa paling tinggi $(0,7 \mathrm{~g} / \mathrm{L}$ media). Jamur ini mempunyai aktivitas enzim selulase sebesar $0,127 \mathrm{unit} / \mathrm{ml}$. Jamur Aspergillus niger PS 1.4 juga tumbuh pada beberapa pestisida: $50 \mathrm{mg} / \mathrm{L}(\mathrm{ppm})$ Clorpirifos, $50 \mathrm{mg} / \mathrm{L}$ Cypermethrin dan 50mg/L Deltamethrin. Jamur Aspergillus niger PS1.4 dapat mendegradasi Deltamethrin sebanyak 90,2\% dalam waktu 10 hari.
\end{abstract}

Kata kunci: Aspergillus niger, deltamethrin, jamur tanah, penguraian, selulosa

\begin{abstract}
A research on selection of cellulose and deltamethrin degrading soil fungi from some environments in West Kalimantan had been done. The aim was to obtain isolates of fungi that have a high ability on decomposing cellulose and deltamethrin. The soil sample was taken from some environments in West Kalimantan, included: peatland, heath forest soil, sediment of manggrove, and coastal soil. Seventy two isolates were able to hydrolize CMC (Carboxy Methyl Cellulose). Aspergillus niger PS 1.4 was able to grow fastest among strains tested and yielded highest of mycelium. The fungi has cellulase activity was $0,127 \mathrm{unit} / \mathrm{ml}$ and able to grow on some pesticides also, included: 50 ppm Chlorpirifos, 50 ppm Cypermethrin and 50 ppm Deltamethrin. Aspergillus niger PS 1.4 was able to degrade deltamethrin as much as $90,2 \%$ in 10 days.
\end{abstract}

Key words: Aspergillus niger, cellulose, deltamethrin, degradation, soil fungi 


\section{PENDAHULUAN}

\subsection{Latar belakang}

Limbah mengandung selulosa banyak dihasilkan oleh sektor pertanian, kehutanan dan perkebunan, diantaranya berupa: jerami padi, tongkol jagung, batang ubi jalar dan ubi kayu, serasah hutan, serbuk gergaji, tandan kosong kelapa sawit (TKKS), kulit biji kopi dan lain-lain. Indonesia sebagai negara agraris menghasilkan limbah lignoselulosa cukup besar. Seperti diketahui bahwa produksi limbah TKKS (tandan kosong kelapa sawit) di Indonesia sangat besar. Apalagi perkebunan kelapa sawit di Indonesia mencapai 10 juta hektar. Dengan asumsi 1 ton CPO menghasilkan sekitar 1,1 ton TKKS. Per tahunnya Indonesia menghasilkan 18 juta ton CPO, artinya sekitar 20 juta ton TKKS dihasilkan per tahun ${ }^{1}$. Jerami juga banyak dihasilkan di sawah-sawah, tahun 2006 Kabupaten Sukoharjo menghasilkan jerami sebanyak 247.110 ton $^{2)}$. Serbuk gergaji juga banyak dihasilkan oleh sector kehutanan. Kabupaten Wonosobo menghasilkan limbah penggergajian kayu berupa serbuk gergaji, sebetan kayu dan potongan kayu sebanyak 1,4 juta $\mathrm{m} 3$ per tahun ${ }^{3)}$.Limbah-limbah tersebut mengandung lignin, selulosa dan hemiselulosa. Padahal selulosa termasuk senyawa recalcitrant, tahan lama, dan terakumulasi di lingkungan terestrial ${ }^{4}$.

Pestisida merupakan bahan kimia beracun yang banyak digunakan di bidang pertanian. Pestisida digunakan secara luas di areal tanaman produksi untuk mengurangi serangan hama dan sekaligus melindungi tanaman dari penurunan hasil dan penurunan kualitas. Salah satu pestisida yang banyak digunakan adalah Deltamethrin. Deltamethrin adalah pestisida pyrethroid buatan yang dapat membunuh serangga melalui kontak kulit dan pencernaan ${ }^{5}$. Senyawa ini banyak digunakan untuk melindungi tanaman di luar ruangan maupun di dalam ruangan melawan hama Lepidoptera, Hemiptera, Coleoptera dan Diptera ${ }^{6}$. Deltamethrin biasanya digunakan pada tanaman kapas, jagung, sereal, kedelai, dan sayur-sayuran ${ }^{7}$. Seperti pestisida yang lain deltamethrin sukar terurai, sering tercuci oleh air hujan dan mengalir ke sungai. Hal ini akan berpengaruh pada kehidupan organisme air dan tanah, untuk itu diperlukan proses degradasi agar tidak mencemari lingkungan.

Beberapa jamur tanah mempunyai kemampuan menguraikan selulosa dan pestisida. Jamur-jamur Aspergillus niger, Chaetomium globosum, Scopulariopsis brevicaulis, Trichoderma koningii dan Trichothecium roseum mempunyai aktivitas selulase pada media serasah dan jerami gandum, sehingga jamur-jamur tersebut dapat menguraikan selulosa ${ }^{8}$. Trichoderma reesei menghasilkan enzim selulase ${ }^{9}$. Penicillium funiculosum telah dikembangkan di Inggris untuk menghasilkan selulase sedangkan dari kelompok Basidiomycetes yaitu Irpex lacteus telah menjadi sumber selulase di Jepang yang disebut Driselase ${ }^{10}$. Jamur Aspergillus niger dapat menghidrolisa herbisida 3-Chloro-2-methyl-p-valerotoulidide menjadi 3-chloro-4-methylacetanilida dan fungisida 2,5-dimethylfuran-3-carboxanilida menjadi acetanilida ${ }^{11}$. Proses ini dapat mengurangi tingkat toksisitas pestisida di lingkungan. Selain itu dilaporkan jamur Rhizoctonia solani dan Fusarium oxysporum dapat mendegradasi pirimiphos-methyl dan carbaril. Dalam 21 hari pirimiphos-methyl dapat terdegradasi $25,6 \%$ dan $16,9 \%$ sedangkan carbaril dapat terdegradasi $15,2 \%$ dan $11,2 \%{ }^{12)}$. Sejauh ini penelitian untuk mengisolasi jamur-jamur tanah di lingkungan ekstrim yang mempunyai kemampuan mendegradasi selulosa dan deltamethrin belum banyak dilakukan, sehingga dilakukan penelitian ini. Lingkungan ekstrim di Kalimantan Barat yang diambil sampel tanahnya adalah tanah gambut, tanah kering, tanah pantai dan tanah manggrove. 


\subsection{Tujuan}

Tujuan penelitian adalah untuk memperoleh isolat jamur yang mempunyai kemampuan tinggi menguraikan senyawa selulosa dan pestisida deltamethrin.

\section{METODOLOGI}

\subsection{Pengambilan sampel tanah}

Pengambilan sampel tanah sebagai sumber mikroba dilakukan pada beberapa lingkungan di Kalimantan Barat. Sampel tanah gambut diambil di Rasaujaya; sampel tanah mangrove diambil di Mempawah dan Singkawang; Sampel tanah kering diambil di desa Koroho kecamatan Mandor. Sampel tanah pantai diambil di Kabupaten Singkawang dan sampel tanah pertanian diambil di Kabupaten Sambas. Sampel tanah kemudian dibawa ke laboratorium untuk dilakukan isolasi jamur tanah yang terdapat di dalamnya.

\subsection{Isolasi jamur}

Sampel tanah sebanyak $1 \mathrm{~g}$ dilarutkan dalam air steril $9 \mathrm{ml}$, kemudian dilakukan pengenceran. Pada pengenceran 10-3 dan 10-4 dilakukan pour plate pada media Taoge agar. Koloni jamur yang tumbuh kemudian dipindahkan pada media baru untuk pemurnian. Isolat jamur yang sudah murni kemudian disimpan dalam test tube berisi media Taoge agar.

\subsection{Pertumbuhan jamur pada media selulosa padat}

Isolat jamur yang sudah murni, kemudian ditumbuhkan pada media selulosa padat $\left(\left(\mathrm{NH}_{4}\right)_{2} \mathrm{SO}_{4} 1 \mathrm{~g} ; \mathrm{MgSO}_{4} 1 \mathrm{~g} ; \mathrm{MnSO}_{4} 1 \mathrm{~g}\right.$; yeast ekstrak $1 \mathrm{~g}, \mathrm{FeCl}_{3} 1 \mathrm{~g}$; agar $18 \mathrm{~g}$; $\mathrm{CMC}$ $10 \mathrm{~g}$; kongo red $1 \mathrm{ml}$; aquadest $1 \mathrm{~L}$ ) pada cawan petri. Kemudian biakan diinkubasi pada suhu kamar selama satu minggu. Setelah itu dilakukan pengamatan, isolat jamur yang membentuk zona bening (clear zone) disekitar koloni berarti menghasilkan enzym selulase. Isolat yang membentuk zona bening kemudian diseleksi lebih lanjut.

\subsection{Pertumbuhan jamur pada media selulosa cair}

Isolat jamur yang membentuk zona bening kemudian ditumbuhkan pada media selulosa cair $\left(\left(\mathrm{NH}_{4}\right)_{2} \mathrm{SO}_{4} 1 \mathrm{~g} ; \mathrm{MgSO}_{4} 1 \mathrm{~g}\right.$; $\mathrm{MnSO}_{4} 1 \mathrm{~g}$; yeast ekstrak $1 \mathrm{~g}, \mathrm{FeCl}_{3} 1 \mathrm{~g}$; CMC $10 \mathrm{~g}$; kongo red $1 \mathrm{ml}$; aquadest $1 \mathrm{~L}$ ). Kultur diinkubasi pada suhu kamar, di atas shaker dengan kecepatan $115 \mathrm{rpm}$. Setelah 6 hari miselium jamur yang tumbuh pada media cair disaring menggunakan kertas saring Whatman No 1 kemudian dikeringkan dalam oven selama 24 jam suhu $80^{\circ} \mathrm{C}{ }^{13}$ ). Setelah itu bobot kering miselium ditentukan, yaitu selisih bobot antara kertas saring kosong dan kertas saring + miselium.

\subsection{Pengaruh pH media terhadap aktivitas enzym selulase}

Isolat jamur ditumbuhkan pada media cair mengandung CMC untuk memperbanyak miselium. Inkubasi dilakukan pada suhu kamar di atas shaker dengan kecepatan 115 rpm. Setelah 6 hari miselium dipanen dengan cara sentrifugasi, kemudian miselium disimpan di dalam bufer sitrat. Untuk menguji pengaruh $\mathrm{pH}$, maka $1 \mathrm{ml}$ suspensi miselium direaksikan dengan $9 \mathrm{ml}$ bufer sitrat mengandung CMC $1 \%$, $\mathrm{pH}$ media diatur 3, 5, 7, 9 dan 11 dengan menambahkan $\mathrm{HCl}$ atau $\mathrm{KOH}$. Kultur diinkubasi pada suhu kamar selama 60 menit, diatas shaker pada kecepatan $115 \mathrm{rpm}$. 0,5 ml filtrat dicampur 1,5 ml DNS dipanaskan dalam water bath selama 5 menit, kemudian didinginkan. Absorbansi untuk menentukan jumlah gula reduksi dibaca pada spektrometer dengan panjang gelombang $540 \mathrm{~nm}$.

\subsection{Pengaruh suhu inkubasi terhadap aktifitas enzym selulase \\ Suspensi miselium sebanyak 1} $\mathrm{ml}$ direaksikan dengan $9 \mathrm{ml}$ bufer sitrat mengandung CMC 1\%, kultur kemudian diinkubasi di atas shaker water bath pada suhu $25^{\circ} \mathrm{C}, 30^{\circ} \mathrm{C}, 40^{\circ} \mathrm{C}, 50^{\circ} \mathrm{C}$ dan $60^{\circ} \mathrm{C}$ selama 60 menit. Absorbansi untuk menentukan jumlah gula reduksi dibaca pada spektrometer dengan panjang gelombang $540 \mathrm{~nm}$. 


\subsection{Pengujian aktifitas enzym selulase}

Untuk menentukan aktivitas enzym selulase, $1 \mathrm{ml}$ suspensi miselium direaksikan dengan $9 \mathrm{ml}$ bufer sitrat mengandung CMC $1 \%, \mathrm{pH}$ media diatur 7,0 . Kultur kemudian diinkubasi di atas shaker water bath pada suhu $40^{\circ} \mathrm{C}$ selama $0,30,60$ dan 90 menit. Filtrat dan miselium jamur dipisahkan menggunakan sentrifugasi. $0,5 \mathrm{ml}$ filtrat ditambah $1,5 \mathrm{mI}$ DNS dipanaskan dalam water bath selama 5 menit, kemudian didinginkan. Absorbansi untuk menentukan jumlah gula reduksi dibaca pada spektrometer dengan panjang gelombang $540 \mathrm{~nm}$.

\subsection{Pertumbuhan jamur pada pestisida}

Isolat jamur terpilih kemudian ditumbuhkan pada media cair berisi ekstrak taoge dan $50 \mathrm{mg} / \mathrm{L}$ (ppm) Deltamethrin, 50 $\mathrm{mg} / \mathrm{L}$ Cypermethrin, $50 \mathrm{mg} / \mathrm{L}$ Chlorpirifos. Kultur diinkubasi di atas shaker dengan kecepatan $115 \mathrm{rpm}$, pada suhu kamar selama 6 hari. Setelah itu miselium jamur disaring menggunakan kertas saring Whatman No 1 kemudian dikeringkan di dalam oven selama 24 jam pada suhu $80^{\circ} \mathrm{C}{ }^{13)}$. Setelah itu bobot kering miselium ditentukan, yaitu selisih bobot antara kertas saring kosong dan kertas saring + miselium .

\subsection{Degradasi pestisida}

Isolat jamur terpilih ditumbuhkan pada media cair mengandung ekstrak taoge dan $50 \mathrm{mg} / \mathrm{L}$ (ppm) Deltamethrin. Kultur diinkubasi pada suhu kamar, diatas shaker dengan kecepatan 115 rpm selama 10 hari. Setelah 10 hari, filtrat dan miselium dipisahkan menggunakan sentrifugasi. Konsentrasi Deltamethrin yang tertinggal ditentukan menggunakan HPLC.

\section{HASIL DAN PEMBAHASAN}

\subsection{Hasil}

Pengambilan sampel tanah sebagai sumber mikroba dilakukan pada beberapa lingkungan berbeda yang terdapat di
Kalimantan Barat. Lingkungan tersebut meliputi: lingkungan gambut, lingkungan pantai, lingkungan payau, lingkungan tanah kering, dan lingkungan pertanian. Setelah dilakukan isolasi, diperoleh 79 nomor isolat. Isolat terbanyak berasal dari tanah gambut $(R)$ yaitu 36 nomor, kemudian tanah gambut berpasir (MD) 13 nomor, tanah pantai 10 isolat, tanah payau 8 isolat, tanah kering 4 isolat, dan tanah pertanian 8 isolat. Setelah ditumbuhkan pada media selulosa padat, sebagian besar membentuk zona bening (Clear zone); 62 isolat membentuk zona bening tipis berdiameter $<0,5 \mathrm{~cm}, 10$ isolat membentuk zona bening besar berdiameter $>0,5 \mathrm{~cm}$ dan 7 isolat tidak membentuk zona bening (Tabel 1).

Sepuluh isolat jamur yang membentuk zona bening tebal (besar) kemudian ditumbuhkan kembali pada media selulosa cair untuk mengamati pertumbuhannya dengan menghitung bobot biomassa (miselium) yang dihasilkan. Isolat PS 1.4 menghasilkan bobot miselium (biomassa) paling tinggi, yaitu $0,7 \mathrm{~g}$ kemudian isolat M2.2 $(0,6 \mathrm{~g})$, isolat M $1.2(0,55 \mathrm{~g})$ kemudian isolat yang lain dan terkecil isolat R $7.5(0,3$ g) (Gambar 1).

Isolat PS 1.4 menghasilkan bobot miselium (biomasa) paling besar, hal ini berkaitan dengan aktifitas enzym selulase yang dihasilkan, semakin besar bobot miselium yang dihasilkan maka semakin besar pula aktifitas enzym selulasenya. Isolat PS1.4 kemudian diidentifikasi dengan mencocokkan morfologi jamur dengan buku identifikasi Compendium of Soil Fungi ${ }^{14)}$ dan Introduction to Food Borne Fungi ${ }^{15)}$. Setelah diidentifikasi Isolat jamur PS 1.4 adalah Aspergillus niger PS1.4.

$\mathrm{pH}$ media juga berpengaruh terhadap aktifitas enzym selulase jamur. Untuk mengetahui $\mathrm{pH}$ optimum yang dibutuhkan agar menghasilkan aktifitas enzym maksimum, maka miselium jamur Aspergillus niger PS1.4 direaksikan dengan bufer sitrat mengandung CMC 1\%. Aktifitas enzym selulase maksimal diperoleh pada $\mathrm{pH} 7$, hal 
Tabel 1. Hasil isolasi jamur dan pembentukan zona bening (clear zone) pada media padat mengandung $\mathrm{CMC}$

\begin{tabular}{|c|c|c|c|c|c|}
\hline No & $\begin{array}{l}\text { Kode } \\
\text { Isolat }\end{array}$ & $\begin{array}{l}\text { Pembentukan } \\
\text { zona bening }\end{array}$ & No & $\begin{array}{l}\text { K o d e } \\
\text { Isolat }\end{array}$ & $\begin{array}{l}\text { Pembentukan } \\
\text { zona bening }\end{array}$ \\
\hline 1 & R1.1 & + & 41 & MD2.2 & + \\
\hline 2 & $\mathrm{R} 1.2$ & + & 42 & MD2.3 & + \\
\hline 3 & R1.3 & + & 43 & MD4.1 & + \\
\hline 4 & $\mathrm{R} 2.1$ & + & 44 & MD4.2 & + \\
\hline 5 & $\mathrm{R} 2.2$ & - & 45 & MD4.3 & ++ \\
\hline 6 & $\mathrm{R} 2.3$ & + & 46 & MD5.1 & + \\
\hline 7 & $\mathrm{R} 2.4$ & + & 47 & MD5.2 & + \\
\hline 8 & R3.1 & - & 48 & MD5.3 & + \\
\hline 9 & R3.2 & + & 49 & MD5.4 & ++ \\
\hline 10 & R3.3 & + & 50 & PS1.1 & + \\
\hline 11 & R3.4 & + & 51 & PS1.2 & + \\
\hline 12 & R3.5 & - & 52 & PS1.3 & + \\
\hline 13 & R4.1 & + & 53 & PS1.4 & ++ \\
\hline 14 & $\mathrm{R} 4.2$ & + & 54 & PS1.5 & + \\
\hline 15 & R4.3 & + & 55 & PS1.6 & + \\
\hline 16 & R4.4 & + & 56 & PS1.7 & + \\
\hline 17 & R4.5 & - & 57 & PS1.8 & + \\
\hline 18 & R4.6 & + & 58 & PS2.1 & + \\
\hline 19 & $\mathrm{R} 4.7$ & + & 59 & PS2.2 & + \\
\hline 20 & R4.8 & + & 60 & Sing1.1 & + \\
\hline 21 & R6.1 & + & 61 & Sing1.2 & + \\
\hline 22 & R6.2 & + & 62 & Sing2.1 & + \\
\hline 23 & R6.3 & - & 63 & Sing 2.2 & + \\
\hline 24 & R6.4 & + & 64 & M1.1 & + \\
\hline 25 & R6.5 & ++ & 65 & M1.2 & ++ \\
\hline 26 & R6.6 & ++ & 66 & M2.1 & + \\
\hline 27 & R7.1 & + & 67 & M2.2 & ++ \\
\hline 28 & R7.2 & + & 68 & K1.1 & + \\
\hline 29 & R7.3 & ++ & 69 & $\mathrm{~K} 1.2$ & + \\
\hline 30 & R7.4 & + & 70 & K2.1 & + \\
\hline 31 & R7.5 & ++ & 71 & $\mathrm{~K} 2.2$ & + \\
\hline 32 & R8.1 & + & 72 & SB1.1 & + \\
\hline 33 & R8.2 & + & 73 & SB1.2 & + \\
\hline 34 & R8.3 & + & 74 & SB3.1 & + \\
\hline 35 & R8.4 & - & 75 & SB3.2 & - \\
\hline 36 & R8.5 & + & 76 & SB3.3 & + \\
\hline 37 & MD1.1 & + & 77 & SB4.1 & + \\
\hline 38 & MD1.2 & + & 78 & SB4.2 & + \\
\hline 39 & MD1.3 & + & 79 & SB4.3 & ++ \\
\hline 40 & MD2.1 & + & & & \\
\hline
\end{tabular}

Keterangan:

- : Tidak terbentuk zona bening

+ : Terbentuk zona bening tipis $(<0,5 \mathrm{~cm})$

++ : Terbentuk zona bening besar $(>0,5 \mathrm{~cm})$

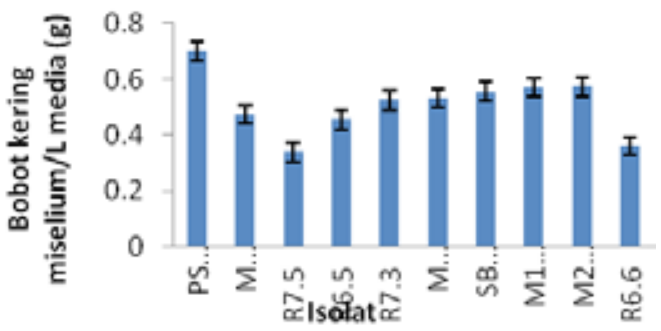

Gambar 1. Pertumbuhan isolat jamur pada media selulosa cair

ini ditunjukkan dengan jumlah gula reduksi yang dihasilkan paling tinggi yaitu 0,2305 mg. Pada $\mathrm{pH} 5$, gula reduksi yang dihasilkan $0,1638 \mathrm{mg}$ dan $\mathrm{pH}$ 9, gula reduksi yang dihasilkan 0,1944 mg (Gambar 2).

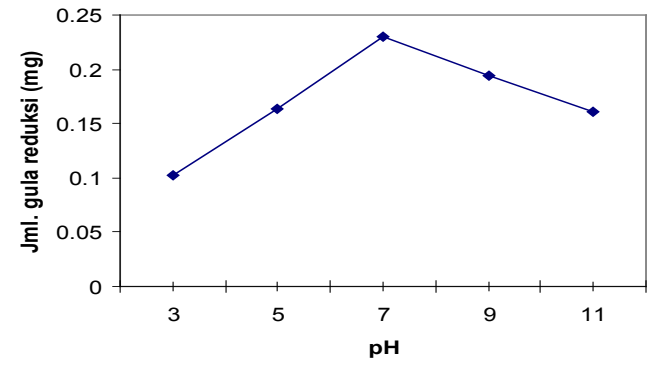

Gambar 2. Pengaruh $\mathrm{pH}$ media terhadap aktifitas enzym selulase jamur Aspergillus niger PS1.4

Suhu atau temperatur inkubasi juga berpengaruh terhadap aktifitas enzym selulase jamur Aspergillus niger PS1.4. Dari Gambar 3 dapat diamati bahwa suhu optimum yang dapat menghasilkan aktifitas enzym selulase maksimal adalah $40^{\circ} \mathrm{C}$. Pada suhu ini dihasilkan gula reduksi paling tinggi yaitu $0.4027 \mathrm{mg}$. Pada suhu $30^{\circ} \mathrm{C}$, gula reduksi yang dihasilkan $0,3110 \mathrm{mg}$ dan suhu $50^{\circ} \mathrm{C}$ dihasilkan gula reduksi $0,3630 \mathrm{mg}$. 


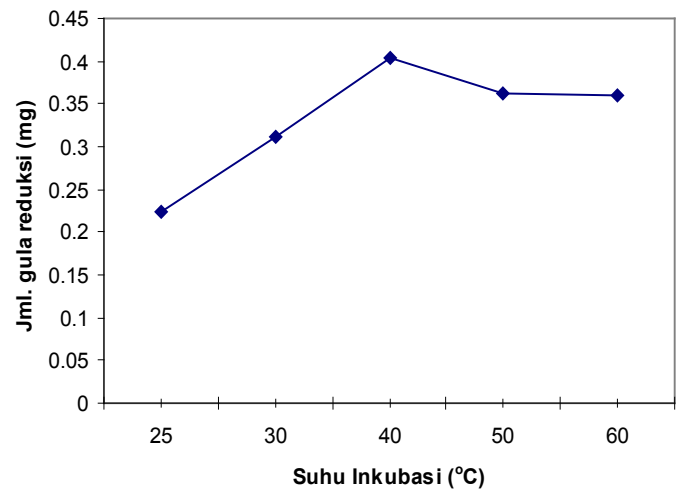

Gambar 3. Pengaruh suhu inkubasi terhadap aktifitas enzyme selulase jamur Aspergillus niger PS 1.4

Untuk menghitung aktifitas enzym selulase, jamur Aspergillus niger PS 1.4 direaksikan dengan bufer sitrat mengandung CMC $1 \%$, dengan $\mathrm{pH}$ media 7,0 dan suhu inkubasi $40^{\circ} \mathrm{C}$. Setelah 30 menit jumlah gula reduksi yang dihasilkan adalah 0,688 mg. Aktivitas enzym selulase: 0,127 unit / $\mathrm{ml}$ (Gambar 4).

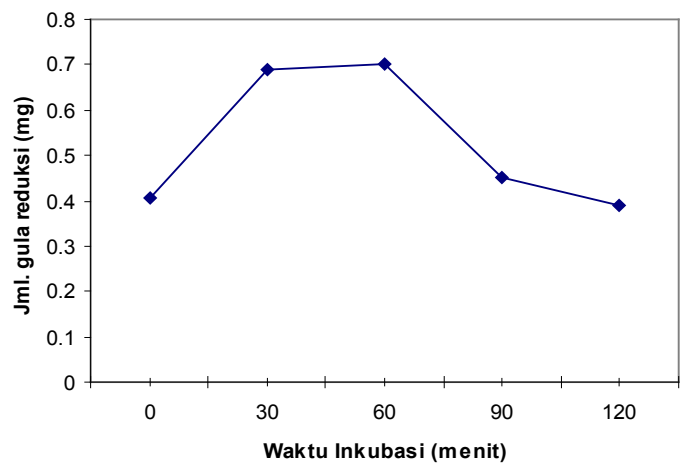

Gambar 4. Aktifitas enzym selulase jamur Aspergillus niger PS 1.4

Enzym selulase yang dihasilkan Aspergillus niger PS 1.4 dapat menghidrolisa selulosa yang terdapat di dalam kayu contoh (test blok). Setelah diinkubasi selama 2 minggu jamur ini dapat menurunkan bobot kering test blok sebesar $1,25 \%$ sedang pada kontrol tidak mengalami penurunan. Hal ini menunjukkan bahwa jamur ini dapat menguraikan senyawa selulosa di dalam kayu test blok.

Jamur Aspergillus niger PS 1.4 kemudian ditumbuhkan pada media mengandung pestisida, yaitu: Chlorofos 50 $\mathrm{mg} / \mathrm{L}$, Cypermethrin $50 \mathrm{mg} / \mathrm{L}$ dan Deltamethrin $50 \mathrm{mg} / \mathrm{L}$. Pada ketiga pestisida tersebut jamur dapat tumbuh. Bobot biomassa paling tinggi diperoleh pada Cypermethrin kemudian Chlorofos dan terendah pada Deltamethrin (Gambar 5).

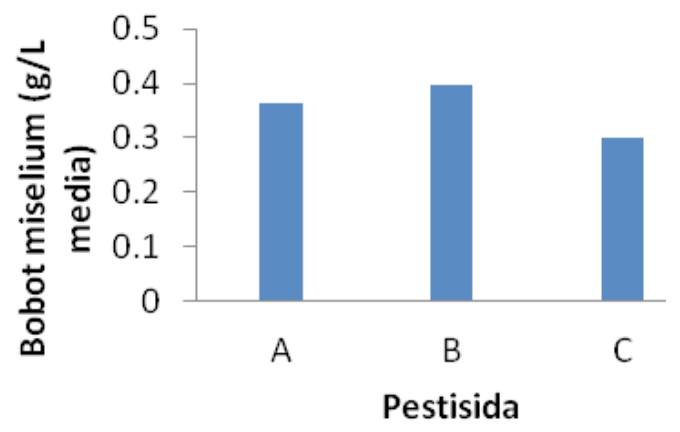

Gambar 5. Pertumbuhan jamur Aspergillus niger PS 1.4 pada 3 macam pestisida

A. Clorofos B. Cypermethrin C. Deltamethrin

Setelah ditumbuhkan pada media mengandung Deltamethrin, ternyata jamur Aspergillus niger PS 1.4 dapat menurunkan konsentrasi deltamethrin sebanyak $90,2 \%$ dalam waktu 10 hari.

\subsection{Pembahasan}

Isolat jamur tanah yang mempunyai kemampuan menguraikan selulosa diperoleh dari beberapa tempat atau lingkungan yang berbeda di Kalimantan Barat. Hal ini dilakukan agar diperoleh jumlah jenis dan macam jamur tanah yang lebih banyak. Namun karena yang diambil tanahnya merupakan lingkungan ekstrim, maka jenis jamur yang mampu tumbuh pada lingkungan tersebut juga tidak banyak. Jenis jamur yang mampu tumbuh di lingkungan ekstrim biasanya memiliki populasi lebih 
besar. Misalnya lingkungan tanah pantai, tanahnya bercampur pasir dan kadar garamnya lebih tinggi, hanya jamur-jamur yang tahan kekeringan dan salinitas tinggi yang mampu tumbuh, dari lingkungan ini diperoleh 10 nomor isolat. Demikian pula di lingkungan payau, tanahnya lembab dan berkadar garam tinggi, dari sini diperoleh 8 nomor isolat. Lingkungan gambut, kondisi gambut di sini sudah bercampur dengan tanah biasa atau gambut yang asli sudah mengalami penguraian. Di lahan gambut ini juga sudah banyak ditanam tanaman pangan seperti jagung, singkong, kacang tanah, cabe, nanas, lidah buaya dll. $\mathrm{pH}$ tanahnya juga juga sudah mendekati netral, yaitu 6,5 tidak seperti lahan gambut yang masih asli biasanya bersifat asam. Di lingkungan ini diperoleh 36 nomor isolat dan ini yang paling banyak. Lingkungan yang paling sedikit perolehan isolatnya adalah tanah kering, disini kelembaban tanah dan kandungan nutrisinya paling rendah, diperoleh 4 nomor isolat. Jumlah keseluruhan isolat yang diperoleh 79 nomor, semua jamur mikroskopis anggota Ascomycetes. Jumlah ini terbilang cukup banyak mengingat lingkungan yang diamati termasuk lingkungan ekstrim, yaitu mempunyai salinitas tinggi, $\mathrm{pH}$ tinggi, kelembaban rendah, kandungan nutrisi rendah dan lain-lain. Jamur mikroskopis yang umumnya anggota Ascomycetes telah teradaptasi dengan baik terhadap lingkungan yang ekstrim. Jamur-jamur ini mempunyai toleransi yang lebih luas terhadap temperatur, $\mathrm{pH}$, kekeringan, konsentrasi oksigen dan radiasi ultraviolet dibandingkan anggota kelompok Basidiomycetes ${ }^{16)}$.

Daerah bening atau clear zone yang terbentuk disekitar koloni jamur merupakan hasil degradasi CMC oleh enzym selulase. Koloni jamur yang membentuk zona bening menunjukkan bahwa jamur tersebut menghasilkan selulase. Besar kecilnya zona bening juga merupakan indikasi awal besar kecilnya aktifitas enzym selulase yang dihasilkan, semakin besar zona bening yang dihasilkan kemungkinan aktifitas enzym selulase yang dihasilkan semakin besar pula. Dari penelitian ini diperoleh 10 isolat jamur yang menghasilkan zona bening besar, sehingga sepuluh isolat tersebut dipilih untuk dilakukan seleksi lebih lanjut. Isolat jamur yang dapat mendegradasi CMC berarti menghasilkan enzym selulase. Carboxymethyl Cellulose (CMC) adalah derivat selulosa yang larut dalam air. Senyawa ini merupakan substrat yang berguna untuk mendeteksi produksi selulase karena cepat didegradasi oleh mikroorganisme ${ }^{17}$.

Jamur yang dapat tumbuh baik pada media mengandung CMC dengan menghasilkan bobot miselium (biomassa) paling tinggi dapat diartikan jamur tersebut mampu memetabolisme selulosa secara maksimal. Dengan kata lain jamur tersebut mempunyai aktivitas enzym selulase paling tinggi. Isolat jamur PS 1.4 menghasilkan bobot miselium paling tinggi, berarti jamur ini mempunyai aktifitas enzym selulase paling tinggi dibandingkan isolat yang lain. Setelah dilakukan identifikasi isolat PS 1.4 adalah Aspergillus niger. Jadi jamur Aspergillus niger PS 1.4 dalam penelitian ini memiliki aktifitas enzym selulase paling tinggi dibandingkan isolat lainnya. Jamur tanah yang mampu mendegradasi selulosa didominasi oleh Aspergillus dan Penicillium. Aspergillus niger dan Mucor hiemalis keberadaannya paling tinggi yaitu $45 \%$ dan $35 \%$ dari sekitar $80 \%$ sampel tanah ${ }^{18}$.

$\mathrm{pH}$ media berpengaruh terhadap aktivitas enzym selulase, dari Gambar 2 terlihat bahwa pada pH 3 dan 11 aktifitas enzym selulase rendah. Hal ini ditandai dengan jumlah gula reduksi yang dihasilkan sedikit. Namun pada pH 7, aktifitas enzym mencapai puncaknya atau paling tinggi. Hal ini berarti aktifitas enzym selulase maksimum pada $\mathrm{pH} 7$ khususnya untuk Aspergillus niger PS 1.4 pada substrat CMC. Hasil ini sesuai dengan penelitian yang menggunakan Aspergillus niger dan Aspergillus nidulan untuk menghasilkan selulase pada media Hyacint dan Czapex-Dox. Aktifitas enzym 
maksimum terjadi pada suhu $35^{\circ} \mathrm{C}$ dan $\mathrm{pH}$ $7,0^{19)}$.

Suhu juga berpengaruh terhadap aktifitas enzym selulase. Dari Gambar 3 terlihat bahwa aktifitas enzym selulase maksimum jamur Aspergillus niger PS 1.4 terjadi pada suhu $40^{\circ} \mathrm{C}$. Di bawah dan di atas suhu tersebut, aktifitas enzym lebih rendah. Penelitian sebelumnya menggunakan Aspergillus niger Z10 untuk menghasilkan enzym selulase pada substrat CMC. Aktifitas enzym selulase maksimum dicapai pada suhu $40^{\circ} \mathrm{C}^{20}$.

Aktifitas enzym selulase jamur Aspergillus niger PS 1.4 menggunakan substrat $\mathrm{CMC}$, pada suhu $40^{\circ} \mathrm{C}$ dan $\mathrm{pH} 7,0$ adalah 0,127 unit/ml. Hasil ini masih lebih besar dibandingkan penelitian menggunakan Aspergillus niger untuk fermentasi serbuk gergaji dan serasah. Aktivitas enzym selulase yang dihasilkan adalah 0,0846 IU/ $\mathrm{ml}$ dan $0,0682 \mathrm{IU} / \mathrm{ml}^{21}$. Peneliti lain meneliti pengaruh suhu $\left(20-50^{\circ} \mathrm{C}\right)$ dan $\mathrm{pH}$ media (49) terhadap aktifitas enzym selulase pada substrat alami seperti serbuk kulit pisang dan serbuk coir. Aktifitas enzym maksimum tercatat pada $\mathrm{pH} 6$ yaitu $0,068 \mathrm{IU} / \mathrm{ml}$ pada serbuk kulit pisang dan $0,049 \mathrm{IU} / \mathrm{ml}$ pada serbuk Coir. Sedangkan suhu tercatat $35^{\circ} \mathrm{C}$ dengan aktifitas enzym 0,072 IU/ml pada kulit pisang dan $0,046 \mathrm{IU} / \mathrm{ml}$ pada serbuk coir $^{22)}$.

Jamur Aspergillus niger menghasilkan enzym selulase yang cukup tinggi, sehingga sering digunakan untuk menghasilkan enzym selulase yang banyak dibutuhkan oleh bidang industri. Sekarang ini tercatat sekitar $20 \%$ enzym selulase yang beredar di pasar dunia, umumnya berasal dari Trichoderma dan Aspergillus ${ }^{20)}$. Selain itu jamur Aspergillus niger juga banyak digunakan untuk penguraian serasah atau bahan lignoselulosa lain dalam pembuatan kompos.

Dalam pertanian organik, jamur Aspergillus niger dapat digunakan sebagai pupuk hayati atau pupuk mikroba. Selain kemampuannya dalam menguraikan selulosa menjadi senyawa $\mathrm{C}$ sederhana, jamur ini juga mampu melarutkan batuan Posfat dalam tanah menjadi senyawa Posfat organik yang siap diserap oleh tanaman. Kemampuan lain jamur Aspergillus niger dapat menghasilkan hormon tumbuh yang dibutuhkan tanaman seperti IAA dan Giberellic Acid. Jamur Aspergillus niger dapat melarutkan CaHPO4 (Ca-P) dan AIPO4 (Al-P). Pelarutan Posfat berhubungan dengan produksi asam, penurunan $\mathrm{pH}$ dan pertumbuhan jamur dalam media kultur 23). Selain itu Aspergillus niger BHUAS01, Penicillium citrinum BHUPCO1 dan Trichoderma harzianum dapat melarutkan tricalcium posfat (TCP) menjadi Posfat terlarut (organik). Kemampuan paling tinggi ditunjukkan $A$. niger $(328 \mu \mathrm{g} / \mathrm{ml})$ kemudian $P$. citrinum $(301 \mu \mathrm{g} / \mathrm{ml})$ dan terakhir T. harzianum $(287 \mu \mathrm{g} / \mathrm{ml})$ sesudah diinkubasi selama 6 hari pada suhu $28^{\circ} \mathrm{C}$. Selain itu jamur ini juga menghasilkan Indole Acetic Acid (IAA), A.niger $(85 \mu \mathrm{g} / \mathrm{ml})$, T. harzianum $(68 \mu \mathrm{g} / \mathrm{ml})$ dan P.citrinum $(52 \mu \mathrm{g} / \mathrm{ml})$ setelah diinkubasi selama 3 hari pada suhu $28^{\circ} \mathrm{C}{ }^{24}$ ). Jamur Aspergillus tubingensis dan Aspergillus niger juga digunakan untuk melarutkan batuan Posfat yang ditambahkan pada tanaman jagung. Hasilnya menunjukkan pertumbuhan tanaman jagung meningkat secara signifikan dan kadar $\mathrm{P}$ organik juga meningkat dibandingkan kontrol ${ }^{25)}$.

Kemampuan lain jamur Aspergillus niger adalah dapat mendegradasi pestisida. Pada penelitian ini jamur Aspergillus niger PS 1.4 dapat tumbuh pada 3 macam pestisida, yaitu Cypermethrin 50 ppm, Clorofos 50 ppm dan Deltamethrin 50 ppm, bahkan jamur ini masih tumbuh pada Deltamethrin 1000 ppm. Setelah dilakukan analisa menggunakan HPLC, jamur Aspergillus niger PS 1.4 dapat menurunkan konsentrasi Deltamethrin sebanyak $90,2 \%$ dalam waktu 10 hari. Deltamethrin dihidrolisa menjadi 3-phenoxybenzaldehid. Dilaporkan bahwa Aspergillus niger mampu mendegradasi endosulfan. Pestisida ini banyak digunakan di India untuk melindungi tanaman kapas, teh, tebu dan sayuran. Jamur 
ini dapat tumbuh pada 400 ppm endosulfan dan dapat mendegradasi sempurna dalam waktu 12 hari ${ }^{26)}$. Selain itu dilaporkan juga bahwa jamur Aspergillus niger dapat menghidrolisa herbisida Solan (3-chloro-4methyl-p-valerotoluidide) menjadi 3-chloro4-methyl acetanilide dan fungicida 2,5 dimethylfuran-3-carboxanilide menjadi acetanilide menggunakan enzym aryl acylamidase11). Jamur Aspergillus niger juga mampu mendegradasi pestisida Omethoate 27).

Beberapa kemampuan di atas tentunya sangat penting, terutama berkaitan dengan penggunaan Aspergillus niger PS 1.4 sebagai pupuk hayati untuk pertanian organik. Pada umumnya lahan pertanian di Indonesia sudah tercemar oleh pestisida. Penggunaan pestisida yang berlebihan meninggalkan residu kimia dalam tanah. Dengan kemampuannya menguraikan pestisida jamur Aspergillus niger PS 1.4 selain sebagai pupuk penyubur tanah, juga dapat berfungsi sebagai agen bioremediasi yang dapat membersihkan tanah pertanian dari residu pestisida, sehingga tanah pertanian menjadi lebih sehat bagi manusia.

\section{KESIMPULAN}

Jamur Aspergillus niger PS1.4 mampu mendegradasi selulosa dan memiliki aktivitas enzym selulase 0,127 unit/ml pada substrat CMC. Jamur ini juga dapat mendegradasi Deltamethrin sebanyak $90,2 \%$ dalam waktu 10 hari.

\section{DAFTAR PUSTAKA}

1. Abimanyu H. 2011. Indonesia-Korea gagas bioetanol dari limbah sawit. Suara Pembaruan (Online). http://www. lipi.go.id/www.cgi.

2. Karyaningsih S, I. Herianti dan T. Suhendrata. 2008. Daya dukung limbah pertanian sebagai sumber pupuk organic di Kab. Sukoharjo. Prosiding Seminar Nasional Teknik Pertanian
2008, Yogyakarta 18-19 November 2008.

3. Anonim. 2012. Kehutanan. Potensi Kabupaten Wonosobo, Selasa 03/04/2012 www.kabupatenwonosobo. com/index.

4. Leschine S. B.1995. Cellulose degradation in anaerobic environments. Annu. Rev. Microbiol. 49:399-426.

5. Bhanu S, S. Archana, K. Ajay, J.L Bhatt, S.P Bajpai, P. S. Singh, B. Vandana. 2011. Impact of deltamethrin on environment, use as an insecticide and its bacterial degradation-a preliminary study. International Journal of Environmental Sciences 1(5): 977980.

6. Dietz S, M de Roman, S. LauckBirkel, Ch. Maus, P. Neumann and R. Fischer. 2009. Ecotoxicological and environmental profile of the insecticide deltamethrin. Bayer Crop Science Journal 62: 211-213.

7. Johnson M, B. Luukinen, K. Buhl, D. Stone. 2010. Deltamethrin Technical Faact Sheet. National Pesticide Information Center, Oregon State University Extention Services. http:// npic.orst.edu/factsheets/Deltatech.pdf

8. Lakshmikant. 1990. Cellulose degradation and cellulase activity of five cellulolytic fungi. World Journal of Microbiology and Biotechnology 6 (1): 64-66.

9. Ahmed. Z, H. Banu, M.M Rahman, F. Akhter and S. Haque. 2001. Microbial activity on the degradation of lignocellulosic polysaccharides. Online Journal of Biological Sciences 1(10): 993-997.

10. Srinivasan. M.C. 1992. Lignocellulose biothenology. Recent Advances and Technology prospect. Oxford and IBH Publishing Co, Pvt. Ltd, New Delhi, India, pp: 315-320.

11. Wallnofer P.R, G. Tillmanns and G. Engelhardt. 2004. Degradation of acylanilide pesticides by Aspergillus 
niger. Pesticide Biochemistry and Physiology, 7 (5): 481-485.

12. Salama A.K, AA. Al-Mihanna and MY. Abdalla. 1999. Microbial degradation of pyrimiphos-methyl and carbaryl by pure culture of two soil fungi. J. King Saud Univ . 11 (1): 25-32.

13. Garraway M.O and R.C Evans. 1991. Fungal Nutrition and Physiology. Krieger publishing Company. Malabar, Florida.p:231.

14. Domsch K.H, W. Gam, T.H Anderson. 1980. Compendium of soil fungi. Academic press, London, New York, Toronto, Sydney, San Francisco.

15. Samson R.A, E.S Hoekstra, C. A.N van Oorschot. 1981. Introduction to food-borne fungi. Centraalbureau Voor Schimmelcultures, Baarn, Delft.

16. Blanchette, R. A. 2000. A review of microbial deterioration found in archaeological wood from different environments. International Biodeterioration and Biodegredation 46:189-204.

17. Hankin L and S.L Anagnostakis. 1977. Solid media containing Carboxymethylcellulose to detect $\mathrm{Cx}$ Cellulaseactivity of microorganisms. Journal of General Microbiology, 98: 109-115.

18. Mahmood K, Y. Wei-jun, K. Nazir, R.Z lqbal and A.G Abdullah. 2006. Study of cellulolytic soil fungi and two nova species and new medium. Journal of Zhejiang University, 7 (6): 459-466.

19. Ali U.F and H.S.S El-Dein. 2008. Pruduction and partial purification of cellulose complex by Aspergillus niger and A. Nidulans grown on water hyacinth blend. Journal of Applied Sciences Research, 4(7): 875-891.

20. Coral G, Arikan B, Unaldi M.N,
Guvenmez H. 2002. Some properties of crude Carboxymethyl Cellulose of Aspergillus niger Z10 wild-type strain. Turk J. Biol, 26: 209-213.

21. Guruchandran $\vee$ and Sasikumar C. 2010. Cellulase production by Aspergillus niger fermented in sawdust and bagasse. Jounnal of Cell and Tissue Research 10 (1): 2115-2117.

22. Kiranmayi M.U, S. Poda, P.B.B.N Charyulu, M. Vijayalakshmi, P.V Krishna. 2011. Studies on influence of natural biowastes on cellulose production by Aspergillus niger. J. Environ. Biol 32: 695-699.

23. Barroso C.B, G.T Pereira, E. Nahas. 2006. Solubilization of CaHPO4 and AIPO4 by Aspergillus niger in culture media with different carbon and nitrogen sources. Brazilian Journal of Microbiology 37:434-438.

24. Yadav J, J.P Verma and K.N Tiwari. 2011. Plant growth promoting activities of fungi and their effect on chickpea plant growth. Asian Journal of Biological Sciences, 4 (3): 291-299.

25. Richa G, B. Khosla and M.S Reddy. 2007. Improvement of maize plant growth by phosphate solubilizing fungi in rock phosphate amended soils. World Journal of Agricultural Sciences 3 (4): 481-484.

26. Bhalerao T.S and P.R Puranik. 2006. Biodegradation of organochlorine pesticide, endosulfan, by a fungal soil isolate, Aspergillus niger. International Biodeterioration and Biodegredation, 59(4): 315-321.

27. Yugui T, W. Yaoming, Y. Shilei, Y. Lianbin. 2008. Optimization of omethoate degradation condition and a kinetic model. International Biodeterioration and Biodegredation 62: 239-243. 